\title{
Stress-responsive gene TauT and acute kidney injury
}

\author{
Xiaobin Han ${ }^{*}$, Russell W Chesney \\ From $17^{\text {th }}$ International Meeting of Taurine \\ Fort Lauderdale, FL, USA. 14-19 December 2009
}

\begin{abstract}
Background: Cisplatin is a commonly used chemotherapeutic agent that has a major limitation because of its nephrotoxicity. We have demonstrated that cisplatin down-regulates the expression of the taurine transporter gene (TauT) in renal cells and that forced overexpression of TauT protects against cisplatin-induced apoptosis in renal cells in vitro and in vivo. In the present study, we have investigated how TauT is regulated by p53 and c-Jun and its role during acute kidney injury (AKI).

Methods: Regulation of TauT by p53 and c-Jun was determined by reporter gene assay, DNA binding, Western blot analysis, and immunohistochemistry.

Results: TauT was down-regulated by p53 and up-regulated by c-Jun. Two potential binding sites for c-Jun were identified in the promoter region of TauT. Inhibition of c-Jun N-terminal kinase (JNK) enhanced TauT promoter activity. Overexpression of TauT protects against cisplatin-induced kidney injury in a TauT transgenic mouse model.

Conclusions: Our findings suggest that TauT plays a critical role in renal function. Expression of TauT is negatively regulated by p53 and positively regulated by c-Jun, which is mediated by the JNK signaling pathway. The outcome level of TauT may determine the fate of renal cells during stress-induced AKI.
\end{abstract}

\section{Background}

Acute kidney injury due to ischemic or toxic renal injury is a common disorder with a mortality of about $50 \%$ $[1,2]$. A vast majority of research in the field has focused on the determination of events and factors that cause renal proximal tubular cell (RPTC) injury and death and lead to the development of AKI. Cisplatin-induced AKI is currently a topic of intense study. As a highly effective chemotherapeutic agent, cisplatin has been used to treat a wide variety of solid tumors [3]. However, $25-35 \%$ of patients experience a significant decline in renal function after the administration of a single dose of cisplatin [4]. Several mechanisms, including oxidation, inflammation, genotoxic damage and cell cycle arrest, have been implicated in cisplatin nephrotoxicity [5-10]. The JNK (c-Jun

\footnotetext{
* Correspondence: xhan@uthsc.edu

Department of Pediatrics, University of Tennessee Health Science Center, and the Children's Foundation Research Center at Le Bonheur Children's

Medical Center, Memphis, Tennessee, USA

Full list of author information is available at the end of the article
}

$\mathrm{N}$-terminal kinase) pathway is a major stress signaling pathway in cells that plays important roles in many cellular processes, including development, apoptosis, cell growth and immune responses [11,12].

Recently, the mechanisms of renal cell repair and regeneration have garnered much attention [7]. Unfortunately, the development of therapeutic strategies that are efficacious in humans with AKI has proven problematic. This suggests that the development of more successful therapies requires approaching the problem from a different vantage point [1]. The regenerative capacity of the kidney is well documented [2], and the responses of surviving RPTC are thought to be crucial to the restoration of renal function following AKI. Consequently, identifying genes that are involved in RPTC protection, repair, and regeneration may uncover new therapeutic targets that promote renal recovery and decrease the severity of AKI.

\section{Biomed Central}




\section{Methods}

\section{Cell culture}

MDCK kidney cells were cultured according to AATC (American Association Tissue Culture) guidelines. Briefly, cells were grown as confluent monolayers in 10 $\mathrm{cm}$ diameter tissue culture plates in DMEM media specific for each cell line with $10 \%$ fetal calf serum at $37^{\circ} \mathrm{C}$ in the presence of $5 \% \mathrm{CO}_{2}$ in a humidified incubator. Cells were plated $18 \mathrm{~h}$ before transfection and fed with fresh medium $4 \mathrm{~h}$ before transfection.

\section{Construction of the reporter gene}

The promoter region of TauT was identified in previous studies [13], and a p53-binding consensus site was found in the TauT promoter sequence, located at -663 to -695 . In this study, $\sim 1.1 \mathrm{~kb}$ of the TauT promoter region DNA was used as the template for PCR (GenBank $^{\mathrm{TM}} / \mathrm{EBI}$ accession number AR151716) and the PCR fragment was cloned into the promoter-less luciferase vector pGL3-Basic (Promega, Madison, WI) to generate the plasmid p963 for use in transfections and luciferase assays. The conditions used were 30 cycles of $1 \mathrm{~min}$ of denaturation at $94^{\circ} \mathrm{C}, 1 \mathrm{~min}$ of annealing at $58^{\circ} \mathrm{C}$, and 1 min of elongation at $72^{\circ} \mathrm{C}$. The sense primer $\left(5^{\prime}-\right.$ GGGGTACCTTACTGAAGGTCACACAGC-3') designed for PCR contained a unique site for KpnI, and the antisense primer (5'-AAGATCTTGGCACGGGAG TTCA-3') contained a unique site for BglII. PCR products were digested with KpnI and BglII and re-ligated into KpnI and BglII sites of pGL3-Basic to generate plasmids containing segments of the TauT promoter sequence extending from the +48 nucleotide corresponding to the transcriptional start site. The constructs were verified by DNA sequencing. The p53-binding site deletion (del pGL-563) and p53 mutation (mt pGL-963) constructs were generated from the p 963 plasmid by using sense primers 5'-GGGGTACCGAGTTGGGGAGGGA-3', and 5'-GGGGTACCAGATGAGG-AAA CCCCCACACAGAAGGTCTGGGGCTTGCCTGAT GTCA-3', respectively. The antisense primer used for these constructs was the same as described above.

\section{Transient transfection}

Plasmid DNA was introduced into cultured MDCK cells using cationic liposomes (LipofectAMINE). Transfection was carried out for 16-18 h, and then cells were washed twice with phosphate-buffered saline and incubated in fresh medium for 24-48 h before harvesting. pGL-control, which contains a luciferase gene driven by the SV40 early region promoter/enhancer, and empty pGLBasic vectors were used as positive and negative controls, respectively. To standardize the transfection efficiency, $0.1 \mu \mathrm{g}$ of $\mathrm{pRL}-\mathrm{CMV}$ vector (pRL Renilla reniformis luciferase control reporter vector; Promega) was cotransfected in all experiments. Cells were harvested $48 \mathrm{~h}$ after transfection and lysed in $200 \mu \mathrm{l}$ of reporter lysis buffer (Promega). A luciferase assay was performed using a dual luciferase assay kit (Promega), and activity was measured with an Optocomp 1 luminometer (MGM Instruments, Inc., Hamden, CT). Promoter activity (mean \pm S.D. of four samples in relative light units) of each construct is represented by relative light output normalized to pRL-CMV control. Graphs represent typical results of four separate experiments. The concentration of protein in the cell extracts was determined using the Bradford method (Bio-Rad, Hercules, CA).

\section{Measurement of taurine transport}

Taurine transport studies were performed on confluent monolayers three days after seeding cells. Briefly, cells were washed with Earle's Balanced Salt Solution (EBSS) at $37^{\circ} \mathrm{C}$. Uptake was initiated by the addition of uptake buffer $(2 \mathrm{mM} \mathrm{KCl}, 1 \mathrm{mM} \mathrm{MgCl}, 96 \mathrm{mM} \mathrm{NaCl}, 1.8 \mathrm{mM}$ $\mathrm{CaCl}_{2}, 5 \mathrm{mM}$ Hepes, pH 7.6) to which $50 \mu \mathrm{M}$ unlabeled taurine and $0.5 \mu \mathrm{Ci} / \mathrm{ml}^{14} \mathrm{C}$-taurine (Perkin Elmer, Boston, MA) were added. After incubation for $30 \mathrm{~min}$ at room temperature, uptake was terminated by the removal of uptake buffer followed by three rapid washes with cold EBSS. Cells were solubilized in $1 \%$ SDS in 0.2 $\mathrm{N} \mathrm{NaOH}$ and radioactivity was counted in a Packard 2000-CA Liquid Scintillation Analyzer.

\section{In vivo model of cisplatin-induced AKI}

Male mice (wild-type and TauT transgenic), 10-12 weeks old and weighing 28 to $30 \mathrm{~g}$, were assigned to treatment groups ( $\mathrm{n}=8 /$ group). For the experiment, eight TauT transgenic mice and eight wild-type mice received a single dose of cisplatin $(15 \mathrm{mg} / \mathrm{kg}$ body weight) by intraperitoneal injection. Eight saline-injected mice were used as controls. To determine cisplatininduced nephrotoxicity, mice were sacrificed three days after cisplatin injection. Kidney samples were collected and treated in $10 \%$ buffered formalin until used.

\section{Western blot analysis}

Cells were lysed in $50 \mu \mathrm{l}$ M-PER mammalian protein extraction reagent (Pierce, Inc., Rockford, IL) supplemented with a protease inhibitor cocktail for use with mammalian cell and tissue extracts (Sigma). The lysates were cleared by centrifugation at $14,000 \times \mathrm{g}$ for $2 \mathrm{~min}$, and the supernatants were transferred to clean tubes. Equal amounts of protein $(50 \mu \mathrm{g})$ were separated by electrophoresis on a $12 \%$ SDS-polyacrylamide gel and transferred to a nitrocellulose membrane (Millipore, Bedford, MA) using a semi-dry electrophoretic transfer 
system (Bio-Rad). Membranes were incubated in 5\% nonfat dry milk in Tris base/sodium chloride (TBS) buffer with $0.2 \%$ Tween 20 (TBST) at $4^{\circ} \mathrm{C}$ overnight. The membranes were incubated with primary antibodies for $1 \mathrm{~h}$ at room temperature. Blots were washed with TBST and incubated with horseradish peroxidase-linked secondary antibody (Sigma) for another hour, and then proteins of interest were detected using a chemiluminescence detection kit (Pierce, Inc.).

Immunohistochemistry

Immunohistochemistry was performed by following the manufacturer's instructions (Pierce). Briefly, samples were rehydrated in decreasing ethanol series $(100 \%$, $95 \%$, and $70 \%$ ) for 5 min each. Samples were immersed in 1x PBS for 5 min at room temperature, then quenching solution $\left(3 \% \mathrm{H}_{2} \mathrm{O}_{2}\right.$ in methanol) for $5 \mathrm{~min}$, and then washed twice in $\mathrm{dH}_{2} \mathrm{O}$ for $10 \mathrm{~min}$. Slides were blocked for 20 min with the blocking buffer. Primary antibodies (antibody against taurine transporter protein) were applied to slides and incubated for $1 \mathrm{~h}$. Slides were washed for $10 \mathrm{~min}$ with PBS, then the biotinylated secondary antibody was applied and incubated for $1 \mathrm{~h}$. After washing for 10 min with PBS, ABC reagent was applied for $30 \mathrm{~min}$. Finally, immunostaining was detected by using a Metal Enhanced DAB Substrate Kit (Pierce).

\section{Assessment of apoptosis}

Apoptotic cells in kidney sections were detected by the terminal deoxynucleotidyl transferase $(\mathrm{TdT})$-mediated digoxigenin-deoxyuridine nick-end labeling (TUNEL) method following the manufacturer's instructions (R\&D Systems, Minneapolis, MN).

\section{Statistics}

All experiments were performed in triplicate. Luciferase assays are expressed in units of relative light output. The data represent the mean \pm standard error of three or four experiments. Statistical comparisons were made using one-way analysis of variance and Student's $t$ test to determine significant differences in the means.

\section{Results}

TauT is directly regulated by c-Jun in renal cells

Our studies have shown that TauT is regulated by several transcription factors, including Sp1, WT1, and p53 [14-16]. Figure 1 depicts the promoter region of TauT and the locations of potential binding sites for indicated transcription factors. Accordingly, several consensus

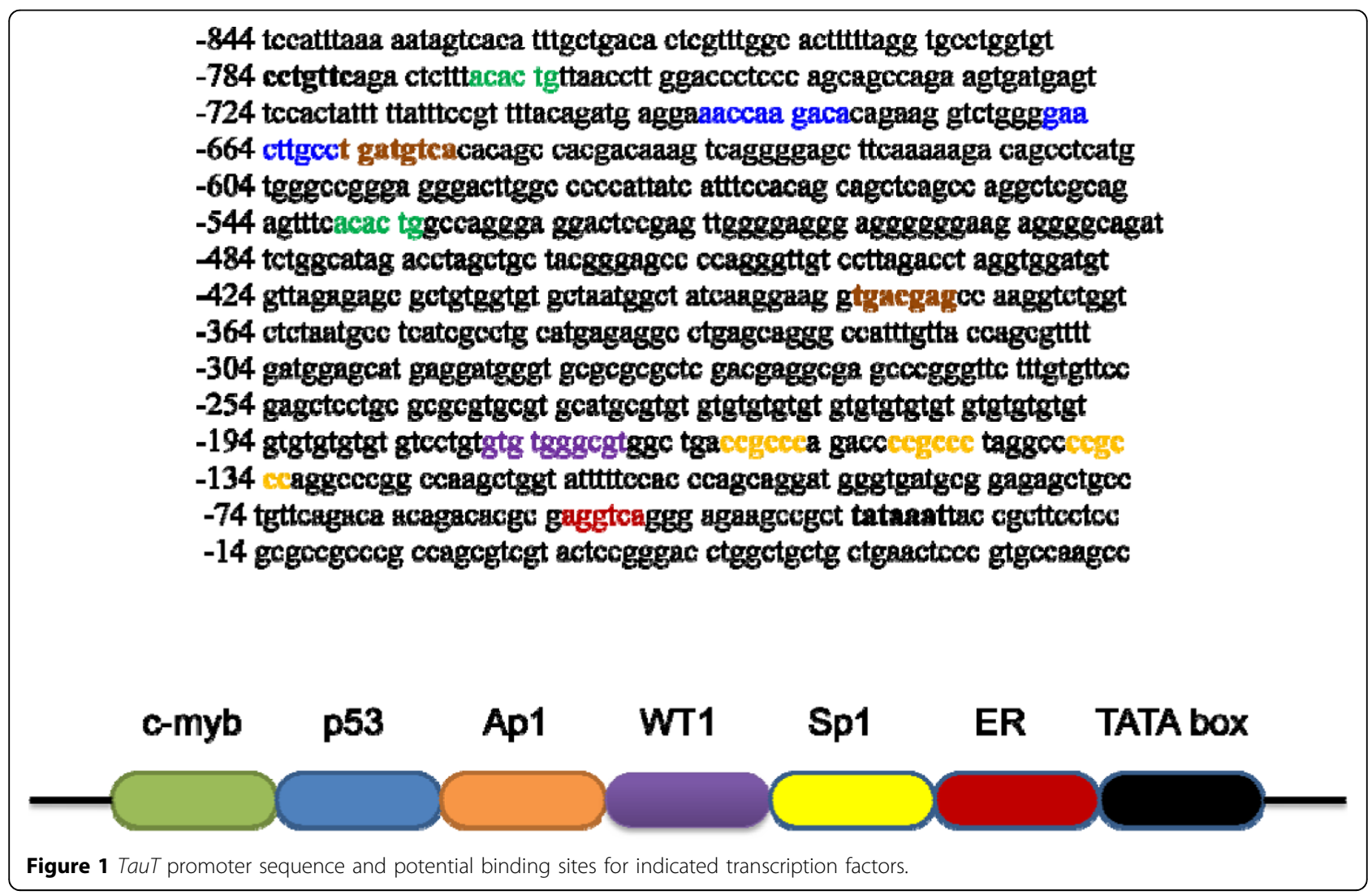


sites for c-Jun/Ap1 are also found in the TauT promoter region. To determine the role of c-Jun in TauT expression, reporter genes were constructed and transiently transfected into MDCK kidney cells. As shown in Figure 2A, co-transfection of c-Jun enhanced TauT promoter activity (pGL3-963). Deletion of the site at -647 reduced the effect of c-Jun, and the effect was totally abolished when both -647 and -391 sites were mutated (Figure 2B \&2C). Electrophoretic mobility shift assays showed that a strong c-Jun binding band was detected when both AP1 sites were presented in the probe. Deletion of the -647 site reduced abundance of the band (lane 3 ).
Double deletion of AP1 sites abolished binding of c-Jun to the TauT promoter (lane 4, Figure 2D).

\section{Osmoregulation of TauT is negatively regulated by JNK}

To determine if JNK signaling is involved in osmoregulation of TauT, MDCK kidney cells were cultured in hypertonic medium $(500 \mathrm{mosmol} / \mathrm{kg}$ ) in the presence of JNK inhibitor SP600125 or negative control 420123 for 24 hours. MDCK cells cultured in normal medium were used as control. Expression of TauT was measured by taurine uptake and reporter gene expression. We found that taurine uptake was significantly increased in cells
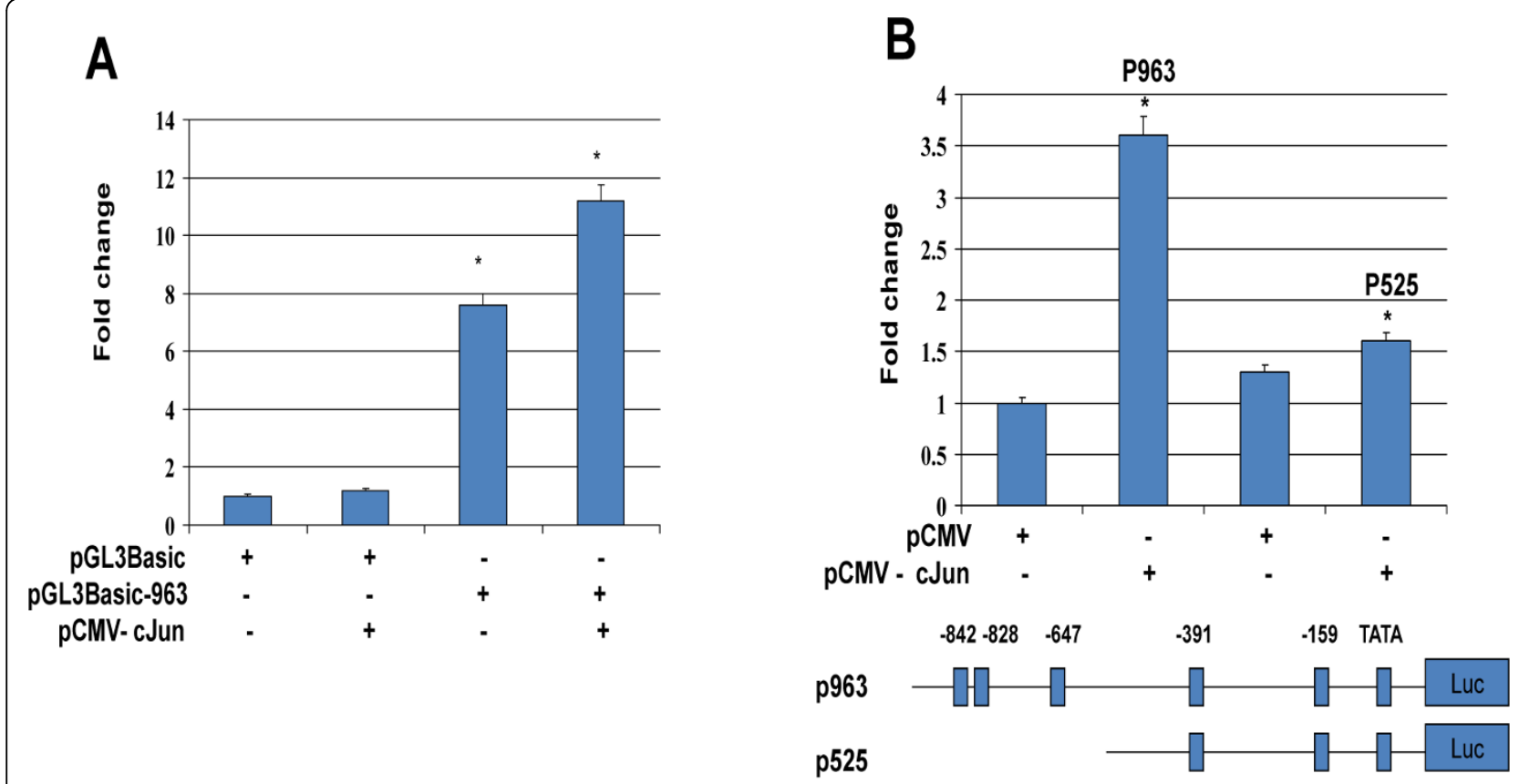

C
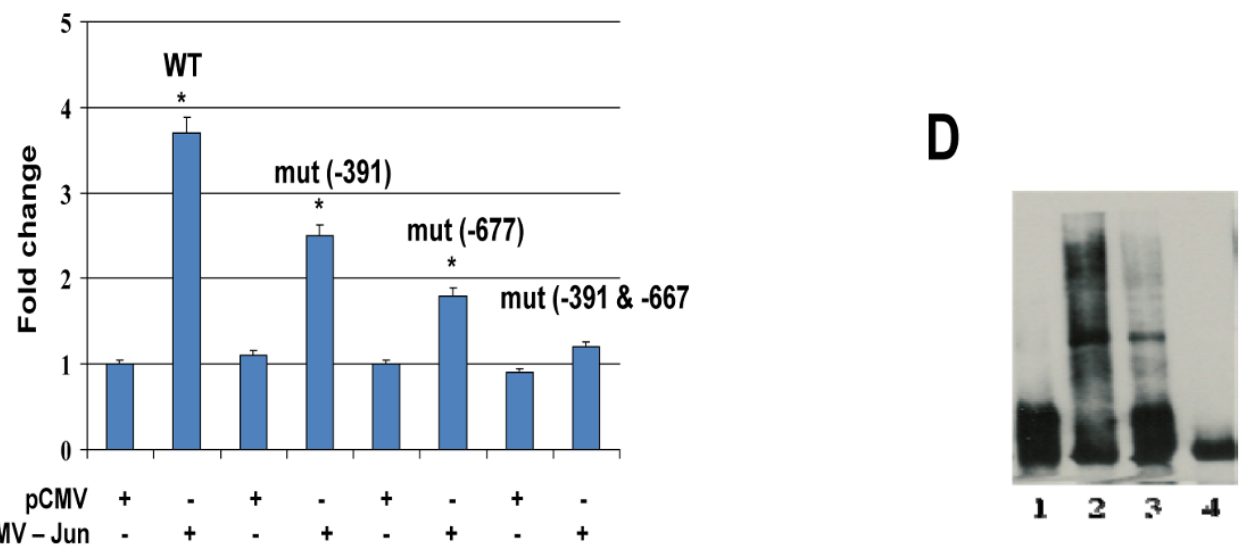

Figure 2 TauT is directly regulated by c-Jun. Reporter genes were transiently transfected in MDCK cells co-transfected with or without C-Jun for $24 \mathrm{~h}$, and then the luciferase assay was performed on cell lysates. A. Reporter gene pGL3-963, which contains two AP1 sites; B. Reporter gene pGL3-525, which contains one AP1 site; C. Reporter gene with double mutation of AP1 sites; D. Electrophoretic mobility shift assays were done using radiolabelled TauT oligonucleotides with nuclear extracts from Rat I cells expressing c-Jun. Lane 1 - control; lane 2 - wt TauT promoter DNA; lane 3 - single AP1 site deletion; and lane 4 - double AP1 site deletion. ${ }^{*} p<0.01$ vs control. 
cultured in hypertonic medium. Inhibition of JNK by SP600125 further enhanced taurine uptake (Figure 3A). A similar result was observed in the reporter gene analysis in these cells (Figure 3B), suggesting that TauT was negatively regulated by JNK during hypertonic stress.

TauT protects against cisplatin-induced AKI by blocking a p53-dependent pathway

Kidney tissues were examined by immunohistochemistry. As shown in Figure 4A, kidney tissue from TauT

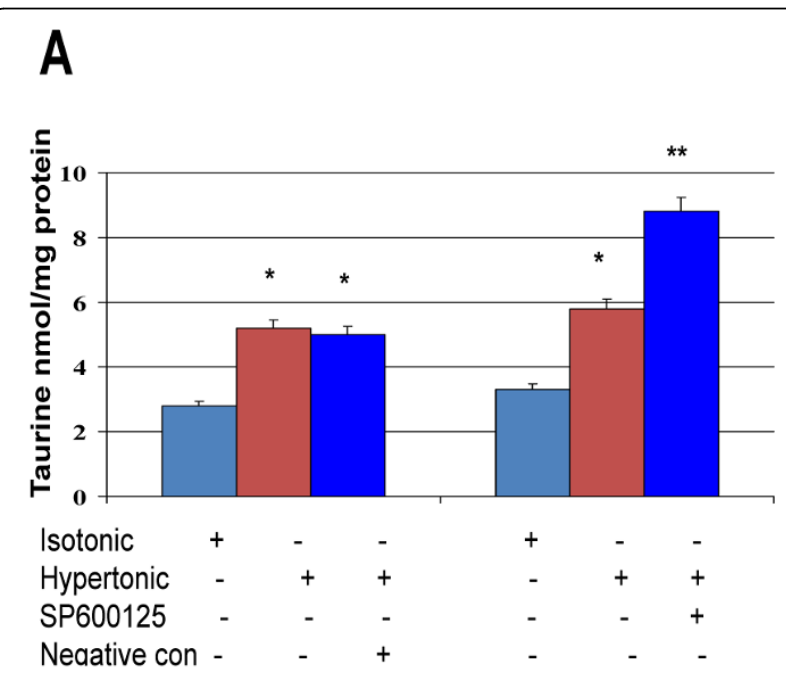

\section{B}

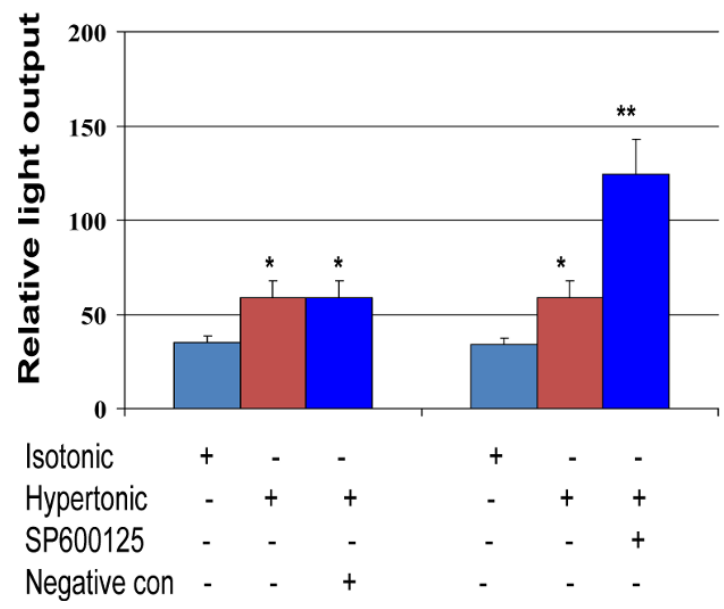

Figure 3 Osmoregulation of TauT is mediated by JNK signaling pathway. MDCK cells were cultured in DMEM medium and treated with 0 or $500 \mathrm{mosmol} / \mathrm{kg}$ JNK inhibitor SP600125 or negative control 420123 for 24 h. A. Taurine uptake; B Reporter gene assay. ${ }^{*} p<0.05$ vs isotonic control; ${ }^{* *} p<0.01$ vs isotonic control. transgenic mice showed stronger immunostaining for TauT protein (TauT) and taurine as compared to that from wild-type (wt) mice. TauT and taurine were mainly found in the S3 segment of proximal tubule cells in normal wt animals, while TauT and taurine were also detected in the outer cortex stripe of TauT transgenic mice.

In saline-treated mice, p53 was detected in both proximal and distal tubular cells. Treatment with cisplatin increased expression of p53 to a similar degree in kidneys of both wt and transgenic animals. Cisplatininduced activation of p53 down-regulated expression of TauT in the kidney from both wt and TauT transgenic mice, which in turn greatly reduced levels of intracellular taurine in the kidneys of both wt and TauT transgenic mice. However, both TauT and taurine were undetectable in cisplatin-treated wt mouse kidney, while signals of immunostaining for TauT and taurine in cisplatin-treated transgenic mouse kidney were still relatively high. In addition, expression of PUMA (p53upregulated modulator of apoptosis) was also found in both proximal and tubular cells, and was elevated in both groups after cisplatin treatment. Interestingly, strong signals of immunostaining for PUMA were observed in the proximal tubules of the ourter cortex stripe, where vast apoptosis was observed in cisplatintreated wt mice but not in cisplatin-treated TauT transgenic mice. We have also found that signals of immunostaining for FasL were higher in cisplatin-treated wt mice, which mainly co-located with p53 and PUMA in the outer stripe of kidney cortex, while FasL was only detected in the kidney medulla of TauT transgenic mice (Figure 4B). Moreover, TUNEL assay revealed clear evidence of cell death in proximal tubules of the cortex outer stripe (Figure 4C) of kidneys from cisplatin-treated wt mice, whereas few numbers of TUNEL-positive tubular epithelial cells were detected in the kidneys of cisplatin-treated TauT transgenic mice. Taken together, these results strongly suggest that TauT plays a critical role in protecting against cisplatin-induced AKI, possibly through blocking the p53-dependent pathway.

\section{Discussion}

Studies have shown that TauT is regulated by variety of stresses, including tonicity, oxidation, DNA damage, and dietary manipulation [17-20], suggesting that TauT is a stress response gene. However, there are little data available about signaling pathway(s) that may be involved in stress-induced TauT regulation. In the present study we have demonstrated that TauT is a target of c-Jun. c-Jun binds to two AP1 consensus sites in the TauT promoter and up-regulates TauT expression in renal cells. Mutation of AP1 sites blocked binding of c-Jun to the TauT promoter and further abolished the effect of c-Jun on 


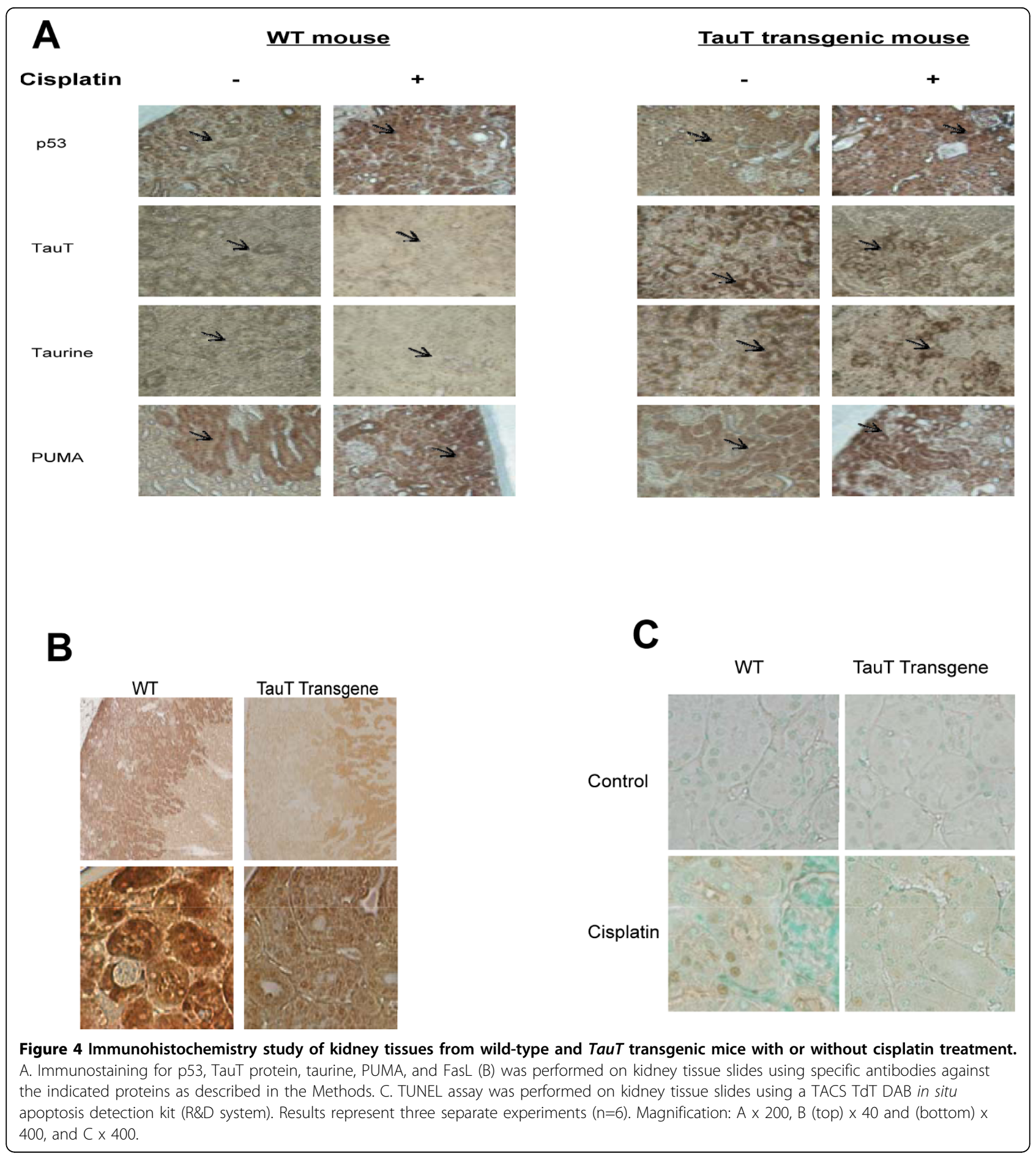

TauT regulation. Interestingly, we have found that expression of TauT as determined by taurine uptake is increased by SP600125, an inhibitor of JNK. It is possible that, binding of taurine to the transporter may contribute to the uptake result, which in turn may also indirectly indicate an increase of TauT on the cell membrane. Taken together, our results suggest that the JNK signaling pathway is involved in the osmoregulation of TauT during hypertonic stress.

The JNK pathway is a major stress signaling pathway in cells that play important roles in many cellular processes, including development, apoptosis and cell growth. In non-stressed cells, JNK targets the ubiquitination and subsequent degradation of bound proteins 
such as c-Jun [21]. In addition, JNK forms a complex with and degrades p53 [22]. However, in stressed cells, JNK phosphorylates and activates associated c-Jun and p53 proteins and enhances their transcriptional regulation of stress-responsive genes [23,24]. Our previous studies have shown that TauT is a target gene of p53. Activation of $\mathrm{p} 53$ by a chemotherapeutic agent (cisplatin) suppresses TauT expression both in vitro and in vivo $[18,25]$. In the present study, we have further demonstrated that treatment with cisplatin increased expression of p53 to a similar degree in kidneys of both wt and transgenic mice. Cisplatin-induced p53 activation repressed TauT to an undetectable level, which in turn resulted in the depletion of taurine in the kidneys of wild-type mice. However, the levels of TauT and taurine in the kidneys of cisplatin-treated TauT transgenic mice are similar to those in the kidneys of normal control animals. Activation of p53 induced PUMA expression in both wt and TauT transgenic mice, although elevated levels of FasL were only observed in the kidneys of wt mice after cisplatin treatment. These findings suggest that relatively normal levels of TauT and/or taurine are able to protect against cisplatin-induced AKI.

Based on these results, we propose a model for p53/cJun-mediated regulation of the TauT gene (Figure 5). Normally, both p53 and c-Jun bind to the TauT promoter and compete to regulate TauT. Therefore, the level of TauT protein is tightly regulated by p 53 and c-Jun via the JNK signaling pathway. In stressed cells, JNK phosphorylates and activates c-Jun and p53 proteins and enhances their transcriptional regulation of TauT. Cisplatin-induced activation of p53 decreases TauT promoter activity via the p53-inhibited JNK-c-Jun pathway by competing with c-Jun for activation. Upon survival signaling, c-Jun substitutes for p53 function and enhances TauT expression. However, mechanisms of TauT

Kidncy cells response to stress

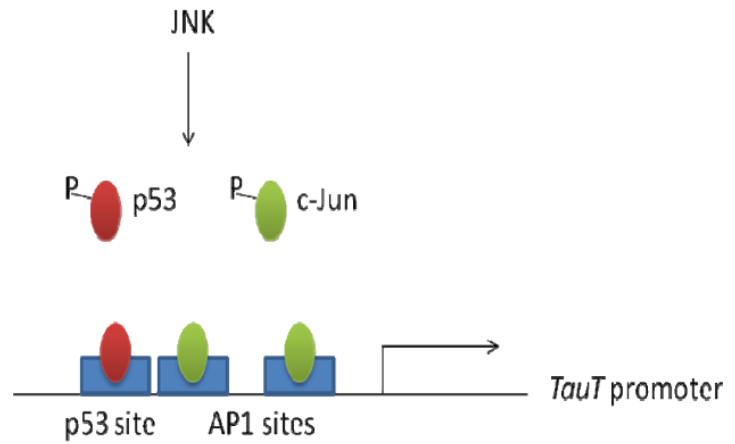

Figure 5 Stress-induced regulation of TauT by p53 and c-Jun via JNK signaling pathway. regulation by $\mathrm{p} 53 / \mathrm{JNK}$-c-Jun pathway during stressinduced kidney injury remain to be determined.

\section{Conclusions}

In the present study, we have shown that expression of TauT is negatively regulated by p53 and positively regulated by c-Jun, which is likely mediated by the JNK signaling pathway. Both p53 and c-Jun bind to and compete to regulate TauT. The ultimate level of TauT expression may determine the fate of renal cells during stress-induced AKI.

\section{List of abbreviations used}

TauT: taurine transporter gene; AKI: acute kidney injury; JNK: c-Jun N-terminal kinase; RPTC: renal proximal tubular cell; AATC: American Association Tissue Culture; EBSS: Earle's Balanced Salt Solution; TUNEL: terminal

deoxynucleotidyl transferase (TdT)-mediated digoxigenin-deoxyuridine nickend labeling.

\section{Acknowledgements}

This article has been published as part of Journal of Biomedical Science Volume 17 Supplement 1, 2010: Proceedings of the 17th International Meeting of Taurine. The full contents of the supplement are available online at http://www.jbiomedsci.com/supplements/17/S1.

The authors wish to thank Andrea Patters for insightful comments and suggestions. The authors also would like to thank Drs. Ioannis Dragatsis of the University of Tennessee Health Science Center transgene core facility for generation of hTauT transgenic mice. This work was supported by grants from the National Kidney Foundation, Le Bonheur Children's Medical Center, and the Le Bonheur Chair of Excellence in Pediatrics.

\section{Authors' contributions}

Authors contributed equally to this work

\section{Competing interests}

The authors declare that they have no competing interests.

\section{Published: 24 August 2010}

\section{References}

1. Kelly $\mathrm{K}$, Molitoris BA: Acute renal failure in the new millennium: time to consider combination therapy. Semin Nephrol 2000, 20:4-19.

2. Thadhani R, Pascual M, Bonventre JV: Acute renal failure. N Engl J Med 1996, 334:1448-460.

3. Lebwohl D, Canetta R: Clinical development of platinum complexes in cancer therapy: an historical perspective and an update. Eur J Cancer 1998, 34:1522-534

4. Ries F, Klastersky J: Nephrotoxicity induced by cancer chemotherapy with special emphasis on cisplatin toxicity. Am J Kidney Dis 1986, 8:368-379.

5. Baliga R, Zhang Z, Baliga M, Ueda N, Shah SV: In vitro and in vivo evidence suggesting a role for iron in cisplatin-induced nephrotoxicity. Kidney Int 1998, 53:394-401.

6. Megyesi J, Safirstein RL, Price PM: Induction of p21WAF1/CIP1/SDI1 in kidney tubule cells affects the course of cisplatin-induced acute renal failure. J Clin Invest 1998, 101:777-782.

7. Price PM, Megyesi J, Saf Irstein RL: Cell cycle regulation: repair and regeneration in acute renal failure. Kidney Int 2004, 66:509-514.

8. Ramesh G, Reeves WB: TNF-alpha mediates chemokine and cytokine expression and renal injury in cisplatin nephrotoxicity. J Clin Invest 2002, 110:835-842.

9. Ramesh G, Reeves WB: TNFR2-mediated apoptosis and necrosis in cisplatin-induced acute renal failure. Am J Physiol Renal Physiol 2003, 285 F610-618.

10. Ramesh G, Reeves WB: Inflammatory cytokines in acute renal failure. Kidney Int 2004, Suppl: S56-61. 
11. Davis RJ: Signal transduction by the JNK group of MAP kinases. Cell 2000, 103:239-253.

12. Kyriakis JM, Avruch J: Mammalian mitogen-activated protein kinase signal transduction pathways activated by stress and inflammation. Physiol. Rev. 2001, 81:807-869.

13. Han X, Patters AB, Jones DP, Zelikovic I, Chesney RW: The taurine transporter: mechanisms of regulation. Acta Physiol (Oxf) 2006, 187:61-73.

14. Han X, Patters AB, Chesney RW: Transcriptional repression of taurine transporter gene (TauT) by p53 in renal cells. J Biol Chem 2002, 277:39266-39273.

15. Han X, Chesney RW: Regulation of taurine transporter gene (TauT) by WT1. FEBS Lett 2003, 540:71-76.

16. Han X, Patters AB, Jones DP, Zelikovic I, Chesney RW: The taurine transporter: mechanisms of regulation. Acta Physiol (Oxf) 2006, 187:61-73.

17. Matsell DG, Bennett T, Han X, Budreau AM, Chesney RW: Regulation of the taurine transporter gene in the $\mathrm{S} 3$ segment of the proximal tubule. Kidney Int 1997, 52:748-754.

18. Han X, Yue J, Chesney RW: Functional TauT protects against acute kidney injury. J Am Soc Nephrol 2009, 20:1323-1332.

19. Askwith T, Zeng W, Eggo MC, Stevens MJ: Oxidative stress and dysregulation of the taurine transporter in high-glucose-exposed human Schwann cells: implications for pathogenesis of diabetic neuropathy. Am $J$ Physiol Endocrinol Metab 2009, 297(3):E620-628.

20. Uchida S, Kwon HM, Yamauchi A, Preston AS, Marumo F, Handler JS: Molecular cloning of the CDNA for an MDCK cell $\mathrm{Na}(+)$ - and $\mathrm{Cl}$ (-)-dependent taurine transporter that is regulated by hypertonicity. Proc Natl Acad Sci U S A 1992, 89(17):8230-8234.

21. Fuchs SY, Xie B, Adler V, Fried VA, Davis RJ, Ronai Z: c-Jun NH2-terminal kinases target the ubiquitination of their associated transcription factors. J. Biol. Chem 1997, 272:32163-32168.

22. Fuchs SY, Adler V, Buschmann T, Yin Z, Wu X, Jones SN, Ronai Z: JNK targets p53 ubiquitination and degradation in nonstressed cells. Genes Dev 1998, 12:2658-2663.

23. Buschmann T, Potapova O, Bar-Shira A, Ivanov VN, Fuchs SY, Henderson S, Fried VA, Minamoto T, Alarcon-Vargas D, Pincus MR, Gaarde WA, Holbrook NJ, Shiloh Y, Ronai Z: Jun NH2-terminal kinase phosphorylation of p53 on Thr-81 is important for p53 stabilization and transcriptional activities in response to stress. Mol. Cell Biol 2001, 21:2743-2754.

24. Derijard B, Hibi M, Wu IH, Barrett T, Su B, Deng T, Karin M, Davis RJ: JNK1: a protein kinase stimulated by UV light and $\mathrm{Ha}$-Ras that binds and phosphorylates the c-Jun activation domain. Cell 1994, 76:1025-1037.

25. Han X, Chesney RW: Regulation of TauT by cisplatin in LLC-PK1 renal cells. Pediatr Nephrol 2005, 20:1067-1072.

\section{Submit your next manuscript to BioMed Central and take full advantage of:}

- Convenient online submission

- Thorough peer review

- No space constraints or color figure charges

- Immediate publication on acceptance

- Inclusion in PubMed, CAS, Scopus and Google Scholar

- Research which is freely available for redistribution 